\title{
Age of Joint Venture, Inter-Firm Technology Transfer and Local Firms' Performance
}

\author{
Sazali Abdul Wahab \\ Graduate School of Management, Universiti Putra Malaysia \\ 43400 Selangor, Malaysia \\ E-mail: saw639@gmail.com \\ Haslinda Abdullah \\ Faculty of Economics \& Management, Universiti Putra Malaysia \\ 43400 Selangor, Malaysia \\ Tel: 60-3-8946-7638Ｅ-mail: hba@putra.upm.edu.my \\ Jegak Uli \\ Faculty of Educational Studies, Universiti Putra Malaysia \\ 43400 Selangor, Malaysia \\ E-mail: jegak@ace.upm.edu.my \\ Raduan Che Rose \\ Faculty of Economics \& Management, Universiti Putra Malaysia \\ 43400 Selangor, Malaysia \\ E-mail: rcr@putra.upm.edu.my
}

\begin{abstract}
The inter-firm technology transfers (TT) through international joint ventures (IJVs), among others, have significantly contributed to a higher degree of local innovation performance/capabilities, technological capabilities, competitive advantage, organizational learning effectiveness, productivity, technological development of local industry, and the economic growth of the host country. Since the focus of inter-firm TT in developing countries has shifted to degree of technology transfer, organizations in developing countries are attempting to assess not only the significant role of technology transfer in strengthening their corporate and human resource performance but also the influence of other critical variables such as MNCs' size, age of JVs (JVAGE), country of origin, and MNC's type of industries that could significantly moderate the relationship. The main objective of this paper is to empirically examine the moderating effect of age of JV (old vs. young JVs) on the relationships between degree of inter-firm technology transfer and two dimensions of local firms' performance: corporate and human resource performances. Using the moderated multiple regression (MMR) analysis, the theoretical models and hypotheses in this study were tested based on empirical data gathered from 128 joint venture companies registered with the Registrar of Companies of Malaysia (ROC). The results revealed that age of JV has significantly affected the relationships between degrees of technology transfer and both dimensions of local firms' performance; where the relationships were found stronger for old JVs as compared to young JVs. The study has bridged the literature gaps in such that it offers empirical evidence and new insights on the significant moderating effects of age of JVs in the relationships between degree of inter-firm technology transfer and local firms' performance using the Malaysian sample.
\end{abstract}

Keywords: Inter-firm technology transfer, Local firms' performance, International joint ventures, Age of joint venture, Malaysia 


\section{Introduction}

When compared to various forms of strategic alliance such as distribution and supply agreements, research and development partnerships or technical and management contract, the international joint ventures (IJVs) are considered as the most efficient formal mechanism for technology transfer (TT) to occur through inter-partner learning between foreign MNCs and local firms (Kogut and Zander, 1993; Inkpen 1998a, 2000). IJVs are also viewed as the most efficient mode to transfer technology and knowledge which is organizationally embedded and difficult to transfer through licensing agreements (Kogut, 1988; Mowery, Oxley and Silverman, 1996). IJVs provide both MNCs and local partners an appropriate avenue to facilitate the transfer of organizational knowledge, particularly for knowledge which is hard to be transferred without the setting up of a JV such as institutional and cultural knowledge (Harrigan, 1984).

A review of literature reveals that most of empirical studies on inter-firm technology and knowledge transfer in strategic alliance particularly IJVs are limiting their focus on the performance of the IJVs (for example Lyles and Salk, 1996; Lane et al., 2001; Tsang et al., 2004; Dhanaraj et al., 2004; Steensma and Lyles, 2000). On the other hand, the performance of the MNCs' subsidiary and affiliate in the host countries has become the primary focus of intra-firm knowledge transfer literature (for example Chen, 1996; Chung, 2001; Cui et al., 2006; Lin, 2003). Most of the studies on strategic alliance and IJVs have recorded positive relationship between knowledge acquisition or transfer and IJVs' performance for example 1) knowledge acquisition has a positive impact on the IJVs' human resource, general and business performance (Lyles and Salk, 1996), 2) knowledge acquisition as a better predictor for human-resource related performance than the general and business performance (Lyles and Salk, 1996), 3) knowledge acquisition from parent firms has a significant positive effect on IJVs' performance (Lane et al., 2001; Tsang et al., 2004), 4) explicit knowledge acquisition have a positive impact on IJVs' performance (Dhanaraj et al., 2004), and 5) tacit knowledge about overseas information was positively related to new product development capacities (Subramaniam and Venkatraman, 2001). In addition, Yin and Bao (2006) found tacit knowledge acquisition had significantly affected local firms' performance (LFP). Surprisingly, Dhanaraj et al. (2004) found tacit knowledge was negatively related to IJVs' performance.

As indicated above, although many studies have acknowledged the significant effect of knowledge transfer on performance outcomes, nevertheless except for Yin and Bao (2006), studies which examine the effects of degree of technology transfer (TTDEG) on both local firms' corporate (CPERF) and human resource (HRPERF) performances in inter-firm TT are still scarce. Moreover, the relationships between TTDEG and both CPERF and HRPERF of local firms could possibly have been influenced by other established moderating factors such as size of MNCs, age of JV, MNCs' country of origin, and MNCs' types of industry. In other words the variations in CPERF and HRPERF could have been significantly influenced or explained by these variables. Thus, this study fills in the literature gaps by specifically examining the effect of age of joint venture (old vs. young JVs) as a moderating variable in the relationships between degree of technology transfer (TTDEG) and two distinct dimensions of local firms' performance (LFP): corporate (CPERF) and human resource (HRPERF) performances. The primary objective is to provide new insights and information on the boundary conditions for TTDEG-LFP relationship (Aguinis, 2004).

\section{Technology Transfer in the Malaysian Context}

In the context of developing country, technology is viewed as an important catalyst of corporate success and national economic growth (Millman, 2001). Due to lack of resource capacities such as weak research and development (R \& D) base, limited investment in R\&D, production and manufacturing capability, weak infrastructure and technological disadvantage (Lado and Vozikis, 1996; Tepstra and David, 1985), Malaysia like other developing countries, mainly depends on FDIs from the multinational corporations (MNCs) as its primary source of technology to enhance the technological capabilities and competitiveness of local industries (Lee and Tan, 2006). This is because MNCs own, produce and control the bulk of world technology in which they undertake nearly $80 \%$ of all private R\&D expenditures worldwide (Dunning, 1993). Therefore, to realize its aspiration in becoming an industrialized and developed nation in 2020, Malaysia must develop and sustain its own technology through appropriate TT strategies and initiatives. Through the Third Industrial Master Plan 2006-2020, Malaysia aims at leveraging the country's existing strength and resources to enhance its competitiveness and resilience to achieve global competitiveness. On the other hand, The Ninth Malaysian Plan 2006-2010 stresses on the importance of developing human capital to strengthen the country's technological capability and capacity to support local innovation through knowledge acquisition and utilization (The Ninth Malaysian Plan, 2006).

In order to achieve this primary objective, foreign technologies are greatly needed by Malaysian firms and industries to build their technological capacity, strengthen their core competencies and expand into technological fields that are critical for maintaining and developing market share (Wagner and Yezril, 1999). Realizing the need for foreign technologies in Malaysia, since 1995 the Ministry of International Trade and Industry (MITI) has accelerated the imports of technology; especially explicit technology, by focusing on investments in high value-added and technology intensive industries. From January 1995 to August 2001, MITI has approved a total of 779 technical and technology 
agreements of which 429 were technical assistance agreement, 172 licensing and patent agreements, 74 trade mark agreements, 27 service agreements, and 26 know-how agreements (MITI, 2004). Between this period (1995-2000), the payment for technology acquisition royalties and fees for the franchises' procurement, use of international brand names, and license for the utilization of new and improved technologies have increased from RM932 million to RM1.6 billion in 2001. Japan was the major source of technology with 443 technical/technology agreements approved, followed by the USA (120), Germany (57), Singapore (24), Korea (18), France (16), Taiwan (13), Australia (13), Switzerland (11), and Netherland (5) (MITI, 2004).

\section{Theory and Hypotheses: Degree of Technology Transfer, Local Firms' Performance and Moderating Effect of Age of Joint Venture}

The current TT issue in developing countries revolves around the extent of degree of technologies that are transferred (TTDEG) by the suppliers to recipient partners (Pak and Park, 2004; Minbaeva, 2007). The question is no longer whether or not the MNCs are transferring technology to local firms; instead the focus in the literature has shifted to questions on 1) the level (sophistication) of the transferred technology, and 2) the stage where the transfer process has reached (Lai and Narayanan, 1997; Narayanan and Lai, 2000). Except for Pak and Park (2004) and Minbaeva (2007), not many studies in both intra and inter-firm TT have focused on TTDEG as independent or dependent variable. In general, bulk of the studies has focused more on technological knowledge and knowledge acquisition 'per se' as the outcomes (dependant variables). For example, the technology transfer, knowledge transfer (KT) and strategic alliance literature have extensively examined the relationships between 1) knowledge attributes, source and recipient and KT success (Cummings et al., 2003), 2) knowledge seekers, knowledge holder and contextual factors and know-how acquisition (Hau and Evangelista, 2007), 3) IJVs characteristics and knowledge acquisition (Lyles and Salk, 1996), 4) knowledge actors' interaction and KT (Bresman et al., 1999), 5) organization motivation, learning capacity, learning hindrance and KT (Simonin, 2004), 6) absorptive capacity and knowledge learned from foreign firm (Lane et al., 2001), 7) the IJV characteristics and knowledge acquisition (Tsang et al., 2004), 8) knowledge antecedents, ambiguity and knowledge transfer (Simonin, 1999a), 9) learning intent, management control and managerial knowledge acquisition (Lin, 2005), 10) relational embeddedness and tacit/explicit knowledge acquisition (Dhanaraj et al., 2004) , 11) overseeing effort, management involvement and knowledge acquisition (Tsang et al., 2004), 12) the supplier and recipient factors and tacit knowledge acquisition (Yin and Bao, 2006), and 13) relation-specific determinants, knowledge specific determinants and degree of knowledge transfer (Pak and Park, 2004).

Although the previous researchers have not specifically dealt with TTDEG as a variable, however, a number of studies have operationalized degree (amount) of technology transferred to the recipient firm in terms of the extent of type of technological knowledge that are transferred or acquired for instance 1) the tacit and explicit marketing knowledge (Hau and Evangalista, 2007), 2) the tacit and explicit knowledge (Dhanaraj et al., 2004; Yin and Bao, 2006), 3) the marketing know-how (Simonin, 1999b; Wong et al., 2002), 4) the technology in service industries (Grosse, 1996), 5) the knowledge on product development and foreign cultures (Lyles and Salk, 1996), 7) the technological learning (Lin, 2007), 8) the managerial knowledge (Si and Bruton, 1999; Tsang 2001; Liu and Vince, 1999; Lin, 2005), 9) managerial skills (Wong et al., 2002), 10) the technology or manufacturing know how (Lam, 1997; Bresman et al., 1999), 11) the business environment and product market knowledge (Geppert and Clark, 2003), and 12) the research and development (Minbaeva, 2007). In the context of inter-firm technological knowledge transfer in IJVs, only Pak and Park (2004) have directly dealt with degree of knowledge transfer as the outcome (dependent variable) with respect to the transfer of new product development and manufacturing skills/techniques.

The TT and KT literature have acknowledged that a substantial transfer of technology regardless whether tacit or explicit technology will positively 1) lead to a higher potentials of innovation performance/capabilities (Guan et al., 2006; Kotabe et al., 2007), 2) increase technological capabilities (Kumar et al., 1999; Madanmohan et al., 2004), 3) enhance organizations' competitive advantage (Liao and Hu, 2007; Rodriguez and Rodriguez, 2005), 4) enhance organizational learning effectiveness (Inkpen, 2000; Inkpen and Dinur, 1998), 5) improve productivity (Caves, 1974; Liu and Wang, 2003), 6) increase technological development of local industry (Markusen and Venables, 1999), and 7) improve the economic growth of the host country (Blomstrom, 1990). In addition, the IJV literature has also suggested that the longer the collaborative relationships the greater the opportunity for JV partners to share, learn and transfer technology and knowledge between them. This is because the duration of relationship is positively associated with frequency of communication and information exchange between partners (Kale et al., 2000; Hallen et al., 1991; Foss and Pedersen, 2002). Nevertheless, duration of JV could also increase the propensity of losing the valuable proprietary asset to the other JV partner (Kale et al., 2000). From the strategic alliance perspective, as an alliance sustains overtime; JVAGE provides several effects such as it intensifies inter-partner trust, changes the bargaining power between partners, and develops partners' personal attachment (Gulati, 1995; Inkpen and Beamish, 1997). Empirical studies have found that the moderating effect of JVAGE has mixed results. Few empirical studies on inter-firm knowledge transfer in IJVs find JVAGE is insignificant in relationship between 1) knowledge acquisition-performance relationship, and 2) organizational characteristics, structural mechanisms, contextual factors, and knowledge acquisition relationship (Tsang 
et al., 2004; Lin, 2005; Lyles and Salk, 1996). Nevertheless, empirical studies have also recorded significant moderating effect of JVAGE on 1) ambiguity-knowledge transfer relationship, and 2) knowledge characteristics-marketing knowledge transfer relationship (Simonin, 1999a, 1999b). Therefore, this study posits as follows:

H1: The relationship between degree of inter-firm technology transfer and local firms' corporate performance is moderated by age of joint venture.

H2: The relationship between degree of inter-firm technology transfer and local firms' human resource performance is moderated by age of joint venture.

\section{Methods}

\subsection{Sample}

The sample frame was taken from the IJV companies registered with the Registrar of Companies (ROC). As at $1^{\text {st }}$ January 2008, the number of IJVs operating in Malaysia was 1038. Out of this, $850 \mathrm{IJVs}$ were considered as active IJVs and $103 \mathrm{IJVs}$ were either dormant or had ceased operation. Since the focus of this study is on inter-firm TT from foreign MNCs to local companies, $85 \mathrm{IJVs}$ were further eliminated from the population frame because only IJVs that have operated more than 2 years and have at least twenty percent $(20 \%)$ of foreign equity are eligible to participate in the survey. Therefore, based on the list provided by ROC, which is considered as the most official and original source of information on foreign investment in Malaysia, it was decided that all IJVs (850) be included in the survey. Data collection was conducted in the period from July 2008 to December 2008 using a self-administered questionnaire. The questionnaires were mailed to 850 active JV companies as listed with ROC using a cover letter. After one month from the posting date the response was found not encouraging. By mid July 2008 there were only 70 responses received from the respondents. Thus, in order to increase the response rate the researcher followed-up through numerous phone calls, e-mails, reminders via letters and personal visits to seek the respondents' cooperation in the survey. After intensive efforts were made, by mid November 2008 a total of 145 responses (17.05\%) were received. Based on literature review, the response rates for mailed questionnaires are usually not encouraging and low (Sekaran, 2003). In the Malaysian context, however, a response rate of $15 \%$ to $25 \%$ is still being considered appropriate and acceptable (Mohammed, 1998; Rozhan, Rohayu and Rasidah, 2001). From 145 responses only 128 questionnaires were usable and 17 questionnaires were returned blank, returned incomplete, or replied but unable to participate in the study.

\subsection{Instrument and measurement}

The main research instrument in this study is the questionnaire. Building on the previous TT and KT studies, the questionnaire adopts a multi-item scales which have been modified accordingly to suit the context of the study: inter-firm TT. Except for degree of technology transfer (TTDEG), all the variables are measured using ten-point Likert Scale $(1=$ strongly disagree to $10=$ strongly agree $)$. For TTDEG, this variable is measured using ten-point Likert Scale $(1=$ very low transfer to $10=$ substantial transfer). The ten-point Likert Scale was selected because 1$)$ the wider distribution of scores around the mean provides more discriminating power, 2) it is easy to establish covariance between two variables with greater dispersion around their means, 3) it has been well established in academic and industry research, and 4) from a model development perspective, a ten-point scale is more preferred (Allen and Rao, 2000).

\subsection{Dependent Variable - Local Firms' Performance (LFP)}

This study operationalizes LFP from two dimensions of performances: 1) corporate performance (CPERF), and 2) human resource (competencies) performance (HRPERF). Based on literature review, the qualitative (objective) measures of companies' performance are the most practical and ideal measurement of performance. However, the concrete financial figures are neither available nor reliable (Lyles and Barden, 2000; Tsang et al., 2004). Past studies have shown a positive relationship between objective and perceptual (subjective) measures of firm's performance (Lyles and Salk, 1996; Dess and Robinson, 1984; Geringer and Hebert, 1989, 1991). Thus, this study applies subjective measures to measure LFP based on IJV's top management assessments using "a multi-dimensional performance indicators". The CPERF, as the first dimension of LFP, is measured by a four (4) items scale measuring business volume, market share, planned goals and profits. For HRPERF, as the second dimension of LFP, four (4) items are used to measure product/service quality, employees' productivity, managerial techniques/skills and operational efficiency (Tsang et al., 2004; Yin and Bao, 2006; Lane et al., 2001; Lyles and Salk, 1996). The Cronbach Alphas for CPERF and HRPERF were 0.926 and 0.97 respectively. The results of Cronbach Alpha were well above of Lyles and Salk (1996).

\subsection{Independent Variable - Degree of Technology Transfer (TTDEG)}

Following Lyles and Salk (1996), Lane et al. (2001), Gupta and Govindarajan (2000), Dhanaraj et al. (2004), Pak and Park (2004), Yin and Boa (2006) and Minbaeva (2007), this study adopts "a multi-dimensional operationalization approach" in measuring this construct. This study operationalizes TTDEG as the transfer of technological knowledge from two dimensions: 1) tacit knowledge (TCTDEG) in terms of new product/service development, managerial systems 
and practice, process designs and new marketing expertise, and 2) explicit knowledge (EXPDEG) in terms of manufacturing/service techniques/skills, promotion techniques/skills, distribution know-how, and purchasing know-how. The respondents were asked to evaluate TTDEG from MNCs to local firms in terms of tacit and explicit dimensions of technological knowledge. The Cronbach Alphas for TCTDEG and EXPDEG were 0.96 and 0.97 respectively. The results of Cronbach Alpha were quite similar to that of Hau and Evangelista (2007) and Yin and Bao (2006).

\subsection{Moderating Variable - Age of Joint Venture (JVAGE)}

In measuring JVAGE this study required the respondents to indicate the JV's number of years in operation based on items coded: $0=$ old joint ventures (number of years $>10$ years) and $1=$ young joint ventures (number of years $<10$ years) (Tsang et al., 2004; Lin, 2005; Simonin, 1999a; Luo, 2001).

\subsection{Model and Analysis}

The moderated multiple regression (MMR) analysis is described as an inferential procedure which consists of comparing two different least-squares regression equations (Aguinis, 2004; Aiken and West, 1991; Cohen and Cohen, 1983; Jaccard et al., 1990). Using the MMR analysis, the moderating effect of the variable (product term) was analyzed by interpreting 1) the $R^{2}$ change in the models obtained from the model summaries, and 2) the regressions coefficients for the product term obtained from the coefficients tables. Prior to conducting the MMR analysis, preliminary analyses were conducted to ensure that there was no violation of the assumptions of normality, linearity, homoscedasticity, and homogeneity of error variance. The population data was carefully examined to avoid the occurrence of 1) Type 1 error; which is the error of rejecting the true null hypotheses at a specified, and 2) Type 2 error ( $\beta$ ); which is the error of failing to reject a false null hypotheses at a specified power (Aguinis, 2004). In this study, Equation 1 below was used to represent the variables in the ordinary least-squares (OLS) model:

Equation 1 (OLS model): $Y=\beta 0+\beta 1 X+\beta 2 Z+e$

To determine the presence of moderating effect, the OLS model was then compared with the MMR model which was represented by Equation 2 below:

Equation 2 (MMR model): $Y=\beta 0+\beta 1 X+\beta 2 Z+\beta 3 X * Z+e$

where, $\mathrm{Y}=$ local firms' performance (CPERF and HRPERF as the dependent variables), $\mathrm{X}=$ degree of technology transfer (TCTDEG and EXPDEG), $Z=a$ hypothesized binary grouping moderator (Age of joint venture; old vs. young JVs), $X * Z=$ the product between the predictors (TTDEG*JVAGE), $\beta 0=$ the intercept of the line-of-best-of-fit which represents the value of $Y$ when $X=0, \beta 1=$ the least-squares estimate of the population regression coefficient for $X, \beta 2$ $=$ the least-squares estimate of the population regression coefficient for $Z, \beta 3=$ the sample-base least-squares estimates of the population regression coefficient for the product term, and $e=$ the error term. The moderating variable (product term) is a binary grouping moderator; where the moderating variable JVAGE was coded using the dummy coding system; $0=$ old JVs, and $1=$ young JVs. This was done because of its simplicity and ease of interpretation of results when making comparisons between different groups (Aguinis, 2004).

\section{Results}

Table 1 and Table 2 show the model summary for both corporate (CPERF) and human resource (HRPERF) performances. The coefficients for all variables for Model 1 and Model 2 (for both CPERF and HRPERF) are presented in Table 3 and Table 4. Table 1 shows that for Model $1, R=.678, R^{2}=.459$ and $[F(2,125)=53.186, p=.0001]$. This $R^{2}$ means that $45.9 \%$ of the variance in the CPERF is explained by TTDEG scores and JVAGE. Model 2 shows the results after the product term (TTDEG*JVAGE) was included in the equation. Table 1 also indicates that the inclusion of the product term resulted in an $R^{2}$ change of $.032,[F(1,124)=7.796, p<0.01]$. The results support for the presence of a moderating effect. To put it differently, the moderating effect of JVAGE explains $3.2 \%$ variance in the CPERF above and beyond the variance by TTDEG scores and JVAGE. Thus, it can reasonably be concluded that hypothesis $H 1$ is supported.

Table 2 shows that for Model $1, R=.736, R^{2}=.541$ and $[F(2,125)=73.710, p=.0001]$. This $R^{2}$ means that $54.1 \%$ of the variance in the HRPERF is explained by TTDEG scores and JVAGE. Model 2 also shows the results after the product term (TTDEG*JVAGE) was included in the equation. Table 2 above indicates that the inclusion of the product term resulted in an $R^{2}$ change of $.027,[F(1,124)=7.662, p<0.01]$. The results also show a presence of significant moderating effect. To put it differently, the moderating effect of JVAGE explains $2.7 \%$ variance in the HRPERF above and beyond the variance by TTDEG scores and JVAGE. Thus, it can safely be concluded that hypothesis $H 2$ is supported. The coefficients table for CPERF as shown in Table 3 depicts the results of the regressions equation for Model 1 and Model 2.

Model 1 indicates that TTDEG was statistically significant $(p<0.001$; Beta value $=0.651)$; however JVAGE was not statistically significant $(p>0.05)$. Equation 3 below shows that for a 1-point increase in TTDEG, the CPERF is predicted to have a difference by .436 , given that the JVAGE is held constant. The regression coefficient associated 
with JVAGE means that the difference in CPERF between old and young JVs is -1.055 , given that TTDEG is held constant.

$$
\text { Equation 3: } C P E R F=10.968+.436 T T D E G-1.055 J V A G E
$$

The high-order of interaction effects of the MMR test was conducted to differentiate the extent of CPERF that was influenced by old and young JVs. Model 2 shows the results after the product term (TTDEG*JVAGE) was included in the equation. As indicated in Table 1 the inclusion of product term resulted in an $R^{2}$ change of $.032,[F(1,124)=7.796$, $p<0.01$. Model 2 shows TTDEG was highly significant $(p<0.001$; Beta value $=.953)$. Both JVAGE and TTDEG*JVAGE were also found to be significant $(p<0.01$; Beta value $=-0.571$ and $p<0.01$; Beta value $=-0.677$, respectively). The results support for the presence of a significant moderating effect. Table 3 also reveals information on the regression coefficients after the inclusion of product term in the equation. The equation for Model 2 is as follows:

\section{Equation 4: $C P E R F=4.390+.638 T T D E G-8.000 J V A G E-.051 T T D E G * J V A G E$}

As indicated above, the interpretation of the regression coefficients is based on the fact that the binary moderator was coded using the dummy code system. The result for Model 2 indicates that for a 1-point increase in the TTDEG, the CPERF is predicted to have a difference by .638 , given that JVAGE is held constant. The interpretation of the regression coefficients for the product term in Equation 4 is that there is a -.051 difference between the slope of CPERF on TTDEG between old and young JVs. In other words, the slope regressing CPERF on TTDEG is steeper for old JVs as compared to young JVs. The TTDEG and CPERF relationship for old and young JVs is shown in Figure 1 below by creating a graph displaying the relationships for each of the groups (Aguinis, 2004). From the results of descriptive statistics, the value of the mean score for TTDEG is 6.19; and for the standard deviation $(S D)$ is 1.30. Following Aguinis (2004), the value $1 S D$ above the mean is 7.49 and the value $1 S D$ below the mean is 4.89 . Thus, using the value of $1 S D$ above and $1 S D$ below mean in Equation 4 yields the graph shown in Figure 1. Results based on Equation 4 led to the conclusion that there was a moderating effect of JVAGE. Figure 1 below shows that the TTDEG-CPERF relationship is stronger (i.e. steeper slope) for old JVs as compared to young JVs. The coefficients table for HRPERF as shown in Table 4 depicts the results of the regressions equation for Model 1 and Model 2.

Model 1 also indicates that TTDEG was statistically significant $(p<0.001$; Beta value $=.741)$; however JVAGE was not statistically significant $(p>0.05)$. Equation 5 shows that for a 1-point increase in TTDEG, the HRPERF is predicted to have a difference by .422, given that the JVAGE is held constant. The regression coefficient associated with JVAGE means that the difference in HRPERF between old and young JVs is .215, given that TTDEG is held constant.

$$
\text { Equation 5: }=3.338+.422 T T D E G+.215 J V A G E
$$

Model 2 shows the results after the product term (TTDEG*JVAGE) was included in the equation. As indicated in Table 2 the inclusion of product term resulted in an $R^{2}$ change of $.027,[F(1,124)=7.662, p<0.01]$. TTDEG was found highly significant $(p<0.001$; Beta value $=1.016)$; whereas both JVAGE and TTDEG*JVAGE were also statistically significant (both at $p<0.01$, Beta value $=-0.435 ; p<0.01$, Beta value $=-0.618$, respectively). The results show the presence of a significant moderating effect. Table 4 also reveals information on the regression coefficients after the inclusion of product term in the equation. The equation for Model 2 is as follows:

$$
\text { Equation 6: HRPERF }=5.222+.579 T T D E G-5.186 J V A G E-.040 T T D E G * J V A G E
$$

The result for Model 2 indicates that for a 1-point increase in the TTDEG, the HRPERF is predicted to have a difference by .579 , given that JVAGE is held constant. The interpretation of the regression coefficients for the product term in Equation 6 is that there was a -.040 difference between the slope of HRPERF on TTDEG between old and young JVs. The slope regressing HRPERF on TTDEG is steeper for old JVs as compared to young JVs. The TTDEG and HRPERF relationship for old and young JVs is also shown in Figure 1. The value of the mean score for TTDEG is 6.19 and for the standard deviation $(S D)$ is 1.30 . The value $1 S D$ above the mean is 7.49 , and the value $1 S D$ below the mean is 4.89. Thus, using the value of $1 S D$ above and $1 S D$ below mean in Equation 6 yields the graph shown in Figure 1. Results based on Equation 6 led to the conclusion that there was a significant moderating effect of JVAGE. Figure 1 below indicates that the TTDEG-HRPERF relationship is slightly stronger (i.e. steeper slope) for old JVs as compared to young JVs.

\section{Discussion and Conclusion}

The inclusion of JVAGE (old and young JVs) in TTDEG-LFP relationship has similar significant moderating effects in changing both local firms' corporate performance (CPERF) $(p<0.01 ; R$ - squared change of 0.032$)$ and local firms' human resource performance (HRPERF) ( $p<0.01 ; R$ - squared change of 0.027). The moderating effect of JVAGE is shown to be capable of changing the nature of relationship and further explains under what conditions TTDEG causes CPERF and HRPERF. This means the presence of significant moderating effect of JVAGE (old and young JVs) exceeded the linear relationships between TTDEG and both CPERF and HRPERF. The result are consistent with recent literature which has strongly supported the significant role of JVAGE (Foss and Pedersen, 2002; Kale et al., 2000; 
Tsang et al., 2004; Simonin, 2004). The results also suggest that JVAGE; whether old or young JVs, has been established to provide a significant moderating impact in TTDEG-CPERF and TTDEG-HRPERF relationships in the $\mathrm{JVs}$; where the relationships were found stronger for old JVs as compared to young JVs.

The results of this study provide critical information in such that although a successful technology transfer in IJVs; which includes the transfer of substantial tacit and explicit knowledge could have significantly increased 1) the corporate performance in terms the local firms' business volume, market share, planned goals and profits, and 2) the human resource performance in terms of local firms' product/service quality, employees' productivity, managerial techniques/skills and operational efficiency, nevertheless, since the technologies which are transferred to local firms mostly originated from the sophisticated and competitive foreign MNCs, the propensity of increasing both CPERF and HRPERF is unlikely to maximize the local firms' performance. This is simply because although a longer period of collaborative relationship in JVs could escalate the opportunity to share, learn, and transfer technologies between JV partners; which is resulted from the decrease of cultural distances, increase of inter-partner trust and personal attachment between partners (Gulati 1995; Yan and Gray, 1994), however, the formation of alliances and JVs have frequently been perceived as 'a race to learn' and are closely associated with JVs' instability. Therefore, a longer duration of JVs may probably cause a shift (increase) in the supplier partners' bargaining power thus eliminating their partner dependency on the recipient partners (Inkpen and Beamish, 1997). As a result, this will indeed frustrate the recipient partners' organizational learning process; when the supplier partners become more protective of their strategic valuable asset and reluctant to transfer higher technologies. On the other hand, the MNCs in young JVs are normally reluctant to invest a higher degree of resources (both capital and human resources) in the newly formed JVs. Their attitude is closely associated with the skeptical feelings towards the recipient partners' true learning intent (whether competitive vs. collaborative) thus limiting the flows of their valuable technologies to recipient partners (Child and Falkner, 1998; Khanna et al., 1998; Hamel, 1991). In this circumstance, as technology flows are strictly restricted and controlled, even if technologies are intentionally transferred, their effects on local firms' performance could be very nominal. The results are explicitly consistent with Dhanaraj et al.'s (2004) who reasoned that tacit knowledge could negatively affected IJVs' performance because 1) tacit knowledge has lagged relationship with IJVs' performance (Lyles and Salk, 1996), 2) the foreign tacit knowledge needs to be adapted to the IJVs and current environment (Martin and Solomon, 2003a, b), and 3) tacit knowledge learning and tacit knowledge utilization are interdependent but distinct (Lane et al., 2001).

One of the major limitations encountered by this study was the resource constraints; where this study has mainly relied on responses obtained from the top management level of the IJVs. Thus, the scope of respondents could have been extended to include the response from middle and lower management levels in the JVs. Secondly, consistent with the literature, the subjectivity of nature of relationship is difficult to capture. Thus, the nature of relationship between IJV partners could have tremendously affected the results if the respondents perceived that the IJVs that they involved in were competitive in nature rather than collaborative. Thirdly, due to lack of awareness on academic research the response rate in terms of the number of usable questionnaires, though sufficient, was not encouraging. This has become a major challenge to many researchers who conduct organization studies in Malaysia. Finally, due to time constraints, the types of technology under investigation in this study were limited to tacit vs. explicit knowledge dimension.

This empirical study is a response to the need for statistical evidence that has typically been lacking in inter-firm TT literature. Since this study focuses on degree of inter-firm TT and local firms' performance, future studies could be conducted to further examine the moderating effects of age of joint venture in the relationships between degree of technology transfer and other critical dependent variable such as partners' conflict, learning outcomes, asymmetric bargaining power, stability of IJVs and equity ownership. Secondly, the above relationship could also be extended to cover other formal and externalized inter-firm TT agents such as direct exporting, FDIs and licensing. Thirdly, it is worthwhile to extend the degree of technology transfer's dimension (tacit vs. explicit dimension) to cover other dimensions of supply chain activities such as production, marketing, management, and distribution. Finally, future studies could further investigate the effects of few other established moderating variables such as organizational culture, collaborative know-how, prior JV experience, and learning capacity on the above relationships to provide new insights and information on the boundary conditions for degree of technology transfer-local firms' performance relationship.

\section{References}

Aguinis, H. (2004). Regression Analysis for Categorical Moderators. New York, The Gilford Press.

Aiken, L. S. \& West, S. G. (1991). Multiple Regression: Testing and Interpreting Interacting. Newbury Park, CA: Sage. Allen, D. R. \& Rao, T. R. (2000). Analysis of Customer Satisfaction Data. United States of America: America Society for Quality.

Blomstrom, M. (1990). Transnational Corporations and Manufacturing Exports from Developing Countries. New York, United Nations. 
Bresman, H., Birkinshaw, J. \& Nobel, R. (1999). Knowledge Transfer in International Acquisitions. Journal of International Business Studies, 30(3), p. 439-62.

Caves, R.E. (1974). Multinational Firms, Competition and Productivity in Host-Country Markets. Economica, 41, p. 176-193.

Chen, E.K.Y. (1996). Transnational Corporations and Technology Transfer to Developing Countries in UNCTAD, Transnational Corporations and World Development, p. 181-214. London, UK: Thompson Business Press.

Child, J. \& Faulkner, D. (1998). Strategies of Cooperation: Managing Alliances Networks and Joint Ventures. Oxford University, New York.

Chung, W. (2001). Identifying Technology Transfer in Foreign Direct Investment: Influence of Industry Conditions and Investing Firm Motives. Journal of International Business Studies, 32(2), p. 211-229.

Cohen, J. \& Cohen, P. (1983). Applied Multiple Regression/Correlational Analysis for the Behavioral Sciences (2 ${ }^{\text {nd }}$ ed.). Hillsdale, NJ: Erlbaum.

Cui, A.S, Griffith, D.A., Casvugil, S.T. \& Dabic, M. (2006).The Influence of Market and Cultural Environmental Factors on Technology Transfer between Foreign MNCs and Local Subsidiaries: A Croatian Illustration. Journal of World Business, 41, p. 100-111.

Cumming, J.L. \& Teng, B.S. (2003). Transferring R\&D Knowledge: The Keys Factors Affecting Knowledge Transfer Success. Journal of Engineering and Technology Management, 20, p. 39-68.

Dess, G. G. \& Robinson, R. B. J. (1984). Measuring Organizational Performance in the Absence of Objective Measures: The Case of the Privately-Held Firm and Conglomerate Business Unit. Strategic Management Journal, 5 (3), p. $265-73$.

Dhanaraj, C., Lyles, M.A., Steensma, H.K. \& Tihanyi, L. (2004). Managing Tacit and Explicit Knowledge Transfer in IJVs: the Role of Relational Embeddedness and the Impact on Performance. Journal of International Business Studies, 35(5), p. 428-42.

Dunning, J. H. (1993). Multinational Enterprise and the Global Economy. Reading, MA: Addison-Wesley.

Foss, N.J. \& Pedersen, T. (2002). Sources of Subsidiary Knowledge and Knowledge Transfer in MNCs. In: Lundan, S., (Eds.). Network Knowledge in International Business, Edward Elgar, Cheltenham, p. 91-114.

Geppert, M. \& Clark, E. (2003). Knowledge and Learning in Transnational Ventures: An Actor-Centred Approach. Management Decision, 41(5), pp.433-442.

Geringer, J. M. \& Hebert, L. (1991). Measuring Performance of International Joint Ventures. Journal of International Business Studies, 22(2), p. 249 - 63.

Guan, J. C., Mok, C. K., Yam, C.M. \& Pun, K. F. (2006). Technology Transfer and Innovation Performance: Evidence from Chinese Firms. Technological Forecasting and Social Change, 73, p.666-678.

Gulati, R., (1995). Does Familiarity Breed Trust? The Implications of Repeated Ties for Contractual Choice in Alliances. Academy of Management Journal 38(1), p. 85-112.

Gupta, A. K. \& Govindarajan, V. (2000). Knowledge Flows within Multinational Corporations. Strategic Management Journal, 21(4), p. 473-96.

Hallen, L, Johanson, J. \& Seyed-Mohamed, N. (1991). Interfirm Adaptation in Business Markets. Journal of Marketing, 55, p. 29-37.

Hamel G. (1991). Competition for Determinant and Interpartner Learning within International Strategic Alliances. Strategic Management Journal, 12, p. 83-103.

Harrigan, K.R. (1984). Joint Ventures and Global Strategies. Columbia Journal of World Business, 19(2), p. 7-16.

Hau, L. N. \& Evangelista, F. (2007). Acquiring Tacit and Explicit Markrting Knowledge from Foreign Partners in IJVs. Journal of Business Research, 60, pp. 1152-1165.

Inkpen, A. C. (1998a). Learning and Knowledge Acquisition through International Strategic Alliances. The Academy of Management Executive, 12(4), p. 69-80.

Inkpen, A.C \& Dinur, A. (1998). Knowledge Management Processes and International Joint Ventures. Organization Science, 9(4), p. 454-468.

Inkpen, A.C. \& Beamish, P.W. (1997). Knowledge Bargaining Power and the Instability of International Joint Ventures. Academy of Management Review, 22(1), p. 177-199.

Inkpen, A.C. (2000). Learning through Joint Ventures: A Framework of Knowledge Acquisition. Journal of Management Studies, 37(7), p. 1019-1043. 
Jaccard, J. J., Turrisi, R., \& Wan, C. K. (1990). Interaction Effects in Multiple Regression. Newbury Park, CA: Sage.

Kale P., Singh H. \& Perlmutter H. (2000). Learning and Protection of Proprietary Assets in Strategic Alliances: Building Relational Capital. Strategic Management Journal, 21(3), p. 217-37.

Khanna, T., Gulati, R. \& Nohria, N. (1998).The Dynamics of Learning Alliances: Competition Cooperation, and Relative Scope. Strategic Management Journal, 19(3), p. 193-210.

Kogut, B. \& Zander, U. (1993). Knowledge of the Firm and the Evolutionary Theory of the Multinational Corporation. Journal of International Business Studies, 24(4), p. 625-646.

Kogut, B. (1988). Joint Ventures: Theoretical and Empirical Perspectives. Strategic Management Journal, 9(4), p. 319-32.

Kotabe, M., Dunlap-Hinkler, D., Parente, R. \& Mishra, H. (2007). Determinants of Cross-National Knowledge Transfer and Its Effect on Firm Innovation. Journal of International Business Studies, 38, p. 259-282.

Kumar, V., Kumar, U. \& Persaud, A. (1999). Building Technological Capability through Importing Technology: The Case of Indonesian Manufacturing Industry. Journal of Technology Transfer. 24, p. 81-96.

Lado, A. \& Vozikis, G. (1996). Transfer of Technology to Promote Entrepreneurship in Developing Countries: An Integration and Proposed Framework. Entrepreneurship Theory and Practice, Winter, p. 55-72.

Lai, Y.W. \& Narayanan, S. (1997). The Quest for Technological Competence via MNCs: A Malaysian Case Study. Asian Economic Journal, 11(4), p. 407-422.

Lam, A. (1997). Embedded Firms, Embedded Knowledge: Problems of Collaboration and Knowledge Transfer In Global Cooperative Venture. Organization Studies, 18(6), pp.973-996.

Lane, P. J., Salk, J.E. \& Lyles, M.A. (2001). Absorptive Capacity, Learning, and Performance in International Joint Ventures. Strategic Management Journal, 22(12), p. 1139-61.

Lee, H. H. \& Tan, H. B (2006). Technology Transfer, FDI and Growth in the ASEAN Region. Journal of the Asia Pacific Economy, 11 (4), p. 394-410.

Liao, S.H. \& Hu, T.C. (2007). Knowledge Transfer and Competitive Advantage on Environmental Uncertainty: An Empirical Study of the Taiwan's industry. Technovation, 27, p. 402-411.

Lin, W.B. (2007). Factors Affecting the Correlation between Interactive Mechanisms of Strategic Alliance and Technological Knowledge Transfer Performance. The Journal of High Technology Management Research, 17, p. 139-155.

Lin, X. (2005). Local Partner Acquisition of Managerial Knowledge in International Joint Ventures: Focusing on Foreign Management Control. Management International Review, 45(2), p. 219-237.

Liu, S. \& Vince, R. (1999). The Cultural Context of Learning in International Joint Ventures. Journal of Management Development, 18 (8), p. 666-675.

Liu, X. \& Wang, C. (2003). Does Foreihn Direct Investment Facilitate Technological Progress? Evidence from Chinese Industries. Research Policy, 32, p. 954-953.

Luo, Y. (2001). Antecedents and Consequences of Personal Attachment in Cross-Cultural Cooperative Ventures. Administrative Science Quarterly, 46(2), p. 177-201.

Lyles, M. A. \& Barden, J. Q. (2000). Trust, Controls, Knowledge Acquisition from the Foreign Parents and Performance in Vietnamese IJVs. Submission to the International Management Division of the AOM meeting.

Lyles, M. A. \& Salk, J.E. (1996). Knowledge Acquisition from Foreign Parents in International Joint Ventures: An Empirical Examination in the Hungarian. Journal of International Business Studies, 29(2), p. 154-74.

Madanmohan, T.R., Kumar,U. \& Kumar, V. (2004). Import-led Technological Capability: A Comparative Analysis of Indian and Indonesian Manufacturing Firms. Technovation, p. 979-993.

Markusen, J.R. \& Venables, A.J. (1999). Foreign Direct Investment as a Catalyst for Industrial Development. European Economic Review, 43, p.335-356.

Martin, X.Y.F. \& Salomon, R. (2003a). Tacitness, Learning, and International Expansion: A Study of Foreign Direct Investments in A Knowledge-Intensive Industry. Organization Science, 14 (3), p. 297-311.

Martin, X.Y.F. \& Salomon, R. (2003b). Knowledge Transfer Capacity and its Implications for the Theory of the Multinational Corporation. Journal of International Business Studies, 34(4), 356-373.

Millman, A. F. (2001). Technology Transfer in the International Market. European Journal of Marketing, 17 (1), p. $26-47$. 
Minbaeva, D. (2007). Knowledge Transfer in Multinationals. Management International Review, 47(4), p. $567-593$.

Ministry of International Trade and Industry (2004). Annual Report. [Online] Available: www. miti.gov.my. (March $\left.18^{\text {th }}, 2007\right)$.

Mohamed, M.Z. (1998). Assessing the Competitiveness of the Malaysian Electronic and Electrical Industry: Part 1-Technology Adoption. Malaysian Management Review, 33(10), p. 19-20.

Mowery, D.C., Oxley J.E. \& Silverman B.S. (1996). Strategic Alliances and Interfirm Knowledge Transfer. Strategic Management Journal, 17, p. 77-91.

Narayanan, S. \& Lai, Y. W. (2000). Technological Maturity and Development without Research: The Challenge for Malaysian Manufacturing. Development and Change, 31, p. 435-457.

Pak, Y. \& Park, Y. (2004). A Framework of Knowledge Transfer in Cross-Border Joint Ventures: An Empirical Test of the Korean Context. Management International Review, 44(4), p. 435-455.

Rodriguez, J.L., Rodriguez, R.M.G. (2005). Technology and Export Behaviour: A Resource-Based View Approach. International Business Review, 14, p. 539-557.

Rozhan, O., Rahayu \& Rashidah. (2001). Great Expectation: CEO's Perception of the Performance Gap of the HRM functions in the Malaysian Manufacturing Sector. Personnel Review, 30 (1), 1\& 2, p. 61-80.

Sekaran, U. (2003). Research Methods for Business. Fourth Edition, John Wiley \& Sons, Inc.

Si, S. X. \& Bruton, G. D. (1999). Knowledge Transfer in International Joint Ventures in Transitional Economy: The China Experience. The Academy of Management Executive, 13(1), p. 83-90.

Simonin, B. L. (1999a). Ambiguity and the Process of Knowledge Transfer in Strategic Alliances. Strategic Management Journal, 20(7), p. 595-623.

Simonin, B. L. (2004). An Empirical Investigation of the Process of Knowledge Transfer in International Strategic Alliances. Journal of International Business Studies, 35(5), 407-27.

Simonin, B.L. (1999b). Transfer of Marketing Know-how in International Strategic Alliances: An Empirical Investigation of the Role and Antecedents of Knowledge Ambiguity. Journal of International Business Studies, 30(3) p. 463-90 [Third Quarter].

Steensma, H. K. \& Lyles, M.A. (2000). Explaining IJV Survival in a Transitional Economy through Social Exchange and Knowledge-based perspectives. Strategic Management Journal, 21(8), p. 831-51.

Subramaniam, M. \& Venkatraman, N. (2001). Determinants of Transnational New Product Development Capability: Testing the Influence of Transferring and Deploying Tacit Overseas Knowledge'. Strategic Management Journal, 22(4): 359-378.

Tepstra, V. \& David, K. (1985). The Cultural Environment of International Business. Cincinnati,, OH: Southwestern Publishing Co.

The Ninth Malaysia Plan. (2006). The Economic Planning Unit. Prime Minister's Department, Putrajaya, Percetakan Nasional Malaysia Berhad.

The Third Industrial Master Plan 2006-2020. Ministry of International Trade and Industry, Putrajaya, Percetakan National Malaysia Berhad.

Tsang E.W.K., Tri D.N. \& Erramilli M.K. (2004). Knowledge Acquisition and Performance of International Joint Ventures in the Transition Economy of Vietnam. Journal of International Marketing, 12(2), p. 82-103.

Tsang, E.W.K. (2001). Managerial Learning in Foreign-Invested Enterprises of China. Management International Review, 41(1), 29-51.

Wong, Y. Y., Maher, T. E., \& Luk, T. K. (2002). The Hesitant Transfer of Strategic Managerial Knowledge to International Joint Ventures in China: Greater Willingness Seems Likely in the Future. Management Review News, 25(1), pp. 1-16.

Yin, E. \& Bao, Y. (2006). The Acquisition of Tacit Knowledge in China: An Empirical Analysis of the 'Supplier-side Individual Level' and 'Recipient-side' Factors. Management International Review, 46(3), p. 327-348. 
Table 1. Model Summary ${ }^{c}$ - Corporate Performance

Model Summaryc

\begin{tabular}{|c|c|c|c|c|c|c|c|c|c|}
\hline \multirow[b]{2}{*}{ Model } & \multirow[b]{2}{*}{$\mathrm{R}$} & \multirow[b]{2}{*}{ R Square } & \multirow[b]{2}{*}{$\begin{array}{l}\text { Adjusted } \\
\text { R Square }\end{array}$} & \multirow[b]{2}{*}{$\begin{array}{l}\text { Std. Error of } \\
\text { the Estimate }\end{array}$} & \multicolumn{5}{|c|}{ Change Statistics } \\
\hline & & & & & $\begin{array}{l}\text { R Square } \\
\text { Change }\end{array}$ & F Change & df1 & df2 & Sig. F Change \\
\hline 1 & $.678^{\mathrm{a}}$ & .459 & .451 & 5.186 & .459 & 53.060 & 2 & 125 & .000 \\
\hline 2 & $.701^{b}$ & .491 & .479 & 5.051 & .032 & 7.796 & 1 & 124 & .006 \\
\hline
\end{tabular}

a. Predictors: (Constant), TTDEG, JVAGE

b. Predictors: (Constant), TTDEG, JVAGE, TTDEG*JVAGE

c. Dependent Variable: CPERF

Table 2. Model Summary ${ }^{c}$ - Human Resource Performance

Model Summaryc

\begin{tabular}{|c|c|c|c|c|c|c|c|c|c|}
\hline \multirow[b]{2}{*}{ Model } & \multirow[b]{2}{*}{$\mathrm{R}$} & \multirow[b]{2}{*}{ R Square } & \multirow[b]{2}{*}{$\begin{array}{l}\text { Adjusted } \\
\text { R Square }\end{array}$} & \multirow[b]{2}{*}{$\begin{array}{l}\text { Std. Error of } \\
\text { the Estimate }\end{array}$} & \multicolumn{5}{|c|}{ Change Statistics } \\
\hline & & & & & $\begin{array}{l}\text { R Square } \\
\text { Change }\end{array}$ & F Change & df1 & df2 & Sig. F Change \\
\hline 1 & $.736^{\mathrm{a}}$ & .541 & .534 & 4.067 & .541 & 73.710 & 2 & 125 & .000 \\
\hline 2 & $.754^{\mathrm{b}}$ & .568 & .557 & 3.962 & .027 & 7.662 & 1 & 124 & .007 \\
\hline
\end{tabular}

a. Predictors: (Constant), TTDEG, JVAGE

b. Predictors: (Constant), TTDEG, JVAGE, TTDEG*JVAGE

c. Dependent Variable: HRPERF

Table 3. Coefficients ${ }^{\mathrm{a}}$ - Corporate Performance

Coefficients $^{a}$

\begin{tabular}{|c|c|c|c|c|c|c|c|c|}
\hline & & \multicolumn{2}{|c|}{$\begin{array}{c}\text { Unstandardized } \\
\text { Coefficients }\end{array}$} & \multirow{2}{*}{$\begin{array}{c}\text { Standardized } \\
\text { Coefficients } \\
\text { Beta }\end{array}$} & \multirow[b]{2}{*}{$\mathrm{t}$} & \multirow[b]{2}{*}{ Sig. } & \multicolumn{2}{|c|}{ 95\% Confidence Interval for B } \\
\hline \multicolumn{2}{|c|}{ Model } & B & Std. Error & & & & Lower Bound & Upper Bound \\
\hline \multirow[t]{3}{*}{1} & (Constant) & 10.968 & 2.493 & & 3.789 & .000 & -2.967 & 6.902 \\
\hline & TTDEG & .436 & .046 & .651 & 9.455 & .000 & .345 & .527 \\
\hline & JVAGE & -1.055 & .964 & -.075 & -1.094 & .276 & -2.964 & .853 \\
\hline \multirow[t]{4}{*}{2} & (Constant) & 4.390 & 2.578 & & 1.703 & .091 & -.713 & 9.493 \\
\hline & TTDEG & .638 & .085 & .953 & 7.493 & .000 & .469 & .806 \\
\hline & JVAGE & -8.000 & 2.659 & -.571 & -3.009 & .003 & -13.262 & -2.738 \\
\hline & TTDEG*JVAGE & -.051 & .018 & -.677 & -2.792 & .006 & -.088 & -.015 \\
\hline
\end{tabular}

a. Dependent Variable: CPERF 
Table 4. Coefficients ${ }^{\mathrm{a}}$ - Human Resource Performance

Coefficients $^{\mathrm{a}}$

\begin{tabular}{|c|c|c|c|c|c|c|c|c|}
\hline \multirow[b]{2}{*}{ Mod } & & \multicolumn{2}{|c|}{$\begin{array}{c}\text { Unstandardized } \\
\text { Coefficients }\end{array}$} & \multirow{2}{*}{$\begin{array}{c}\text { Standardized } \\
\text { Coefficients } \\
\text { Beta } \\
\end{array}$} & \multirow[b]{2}{*}{$\mathrm{t}$} & \multirow[b]{2}{*}{ Sig. } & \multicolumn{2}{|c|}{ 95\% Confidence Interval for B } \\
\hline & & B & Std. Error & & & & Lower Bound & Upper Bound \\
\hline \multirow[t]{3}{*}{1} & (Constant) & 3.338 & 1.955 & & 1.707 & .090 & -.531 & 7.207 \\
\hline & TTDEG & .422 & .036 & .741 & 11.675 & .000 & .351 & .494 \\
\hline & JVAGE & .215 & .756 & .018 & .285 & .776 & -1.281 & 1.712 \\
\hline \multirow[t]{4}{*}{2} & (Constant) & 5.222 & 2.023 & & 2.582 & .011 & 1.218 & 9.225 \\
\hline & TTDEG & .579 & .067 & 1.016 & 8.671 & .000 & .447 & .711 \\
\hline & JVAGE & -5.186 & 2.086 & -.435 & -2.486 & .014 & -9.314 & -1.057 \\
\hline & TTDEG*JVAGE & -.040 & .014 & -.618 & -2.768 & .007 & -.069 & -.011 \\
\hline
\end{tabular}

a. Dependent Variable: HRPERF

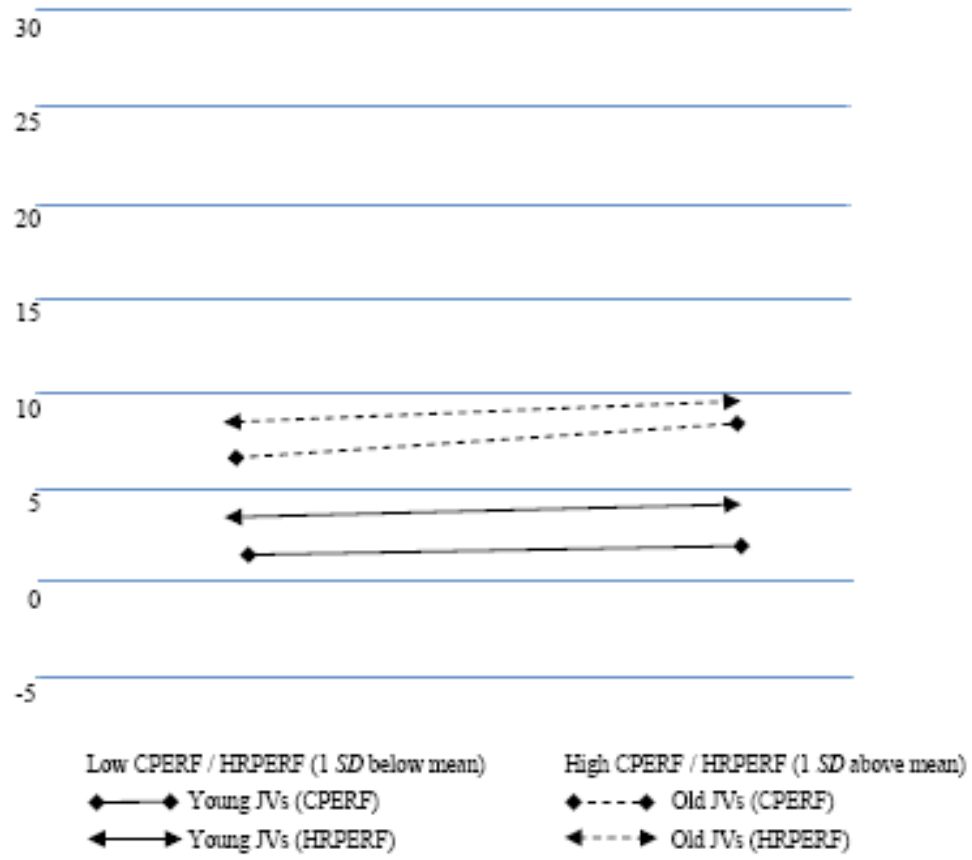

Figure 1. Slopes for both CPERF and HRPERF on TTDEG for JVAGE 